\title{
Flood disaster risk in Jakarta, Indonesia
}

\author{
A. Neolaka \\ Department of Civil Engineering, Faculty of Technology, \\ State University of Jakarta, Indonesia
}

\begin{abstract}
This research aims at investigating the level of environmental awareness knowledge on the part of Jakarta community members in anticipating the huge flood that occurs annually in Jakarta city and its neighbouring areas. Survey and field observation have been employed in this research that focuses on the eastern part of Jakarta. A total number of 160 respondents from 40 families have been involved in the study. They consist of parents and their $\geq 16$-year-old sons and daughters who were asked to complete a questionnaire for this research. Findings show (1) a knowledge sub-indicator level of $21.88 \%$ for environmental awareness and $43.12 \%$ for flood risks; whereas, (2) sub-indicator related to attitude towards environment of the community members living in flood-prone area is $47.25 \%$. This later figure is an average of several indicators. When each of these indicators is observed, we can see a very low indicator of environmental related behaviour; i.e. people who are not disappointed with the existence of illegal buildings along the river flow reach $28.75 \%$. By careful observation of the indicators, we can identify one indicator that signifies very poor environmental behaviour; i.e. the community are not disappointed to see the rows of illegal constructions along the river banks. Interviews with the community, represented by parents, reveal that they understand about the risks of yearly floods, know that they must dispose waste/trash in proper place, and comprehend that they should keep the drainage system in front of their houses free of trash/garbage. However, their knowledge is not reflected in their daily living practices. The Jakarta Community does not have sufficient environmental awareness that their effort to control/manage the risk of floods is very poor. It gets worse by their negative attitude about moving out from the flood-prone areas (43.7\%). Findings of this research are supported by what actually happens in Jakarta as flood occurs every time it rains. In conclusion, public environmental awareness in Jakarta, focused on anticipating the occurrence of floods, is quite poor. This has been the
\end{abstract}


influence of socio-cultural diversity, difficulty in obtaining employment, and poverty. People do not even have the chance to think about caring for their environment despite the fact that their living practices can bring about disaster to them.

Keywords: flood risk, behavioural, environmental awareness, community of Jakarta.

\section{Introduction}

Jakarta as the capital of the Republic of Indonesia attracts the world's attention for there is always a flood every time it rains. As the nation's capital, as well as the centre of economic activities, trade, education, industry, tourism and others, indeed, Jakarta has become a major destination for many individuals of varied cultural backgrounds to earn a living. Their different sociocultural backgrounds have impact on the level of concern they have for their environment. This is reflected in their daily life behaviour that does not proactively maintain their immediate living environment. According to sociology theory, a society that consists of social groups of different cultural background, ethnicity, race, ideology, traditions, behaviours, etc., allows the occurrence of disagreements that lead to conflicts and encourage changes in society. Natural disasters such as floods can lead people who live in the affected areas to migrate to a safer place. Sometimes the floods caused by the actions of citizens themselves, for example; cutting down the forest/tree in an area set aside for water catchment, disposing trash is not in place and so on [1]. This sociological theory reinforces the notion that Jakarta with its variety of social, culture, and traditions will strive to keep up with the difficult economic life, frequent conflicts and frictions in life, and lead people to an unintentional lack of concern for their living environment. Those who came to Jakarta to find work and settle down are from various regions across Indonesia; they also have diverse living traditions and culture. Thus, it is difficult to unite the mindset of newcomers with that of the natives and migrants who have been living in Jakarta for a long time. It is expected that the mindset of this diverse population is set to care about the environment, so that Jakarta is spared from catastrophic floods that often take place every year. The increasing level of urbanization that aims at finding employment for better life or economic status is not achieved but turns into suffering, since it is difficult to obtain employment, and the result is poverty. This has incurred even more problems to the local government. In these circumstances, the level of public awareness of the environment will be reduced or low. Thus, the flood is essentially created by the people themselves. So far the government has dealt with floods by helping communities hit by disasters, manage waste disposal, asking people in floodprone location to move to other places, as well as other efforts. The risk of floods becomes more severe due to the high population density. The population of Jakarta at night is $8,522,545$ or more than 10 million people during the day due to the arrival of workers from outside the city. East Jakarta is the most populous part of the city with 2,626,708 people (see Table 1). 
Table 1: $\quad$ Population and area of DKI Jakarta: month: February 2011.

\begin{tabular}{|l|c|c|c|c|c|c|c|}
\hline \multirow{2}{*}{ Region } & \multicolumn{3}{|c|}{ Indonesian Citizens } & \multicolumn{3}{c|}{ Foreign Citizens } & \multirow{2}{*}{ Total } \\
\cline { 2 - 7 } & Male & Female & Sum & Male & $\begin{array}{c}\text { Femal } \\
\text { e }\end{array}$ & Sum & \\
\hline $\begin{array}{l}\text { Central } \\
\text { Jakarta }\end{array}$ & 503,411 & 418,822 & 922,233 & 191 & 146 & 337 & 922,570 \\
\hline $\begin{array}{l}\text { North } \\
\text { Jakarta }\end{array}$ & 776,582 & 644,973 & $1,421,555$ & 269 & 240 & 509 & $1,422,064$ \\
\hline $\begin{array}{l}\text { West } \\
\text { Jakarta }\end{array}$ & 869,057 & 765,332 & $1,634,389$ & 334 & 302 & 636 & $1,635,025$ \\
\hline $\begin{array}{l}\text { South } \\
\text { Jakarta }\end{array}$ & $1,062,260$ & 831,361 & $1,893,621$ & 408 & 251 & 659 & $1,894,280$ \\
\hline $\begin{array}{l}\text { East } \\
\text { Jakarta }\end{array}$ & $1,426,586$ & $1,199,896$ & $2,626,482$ & 121 & 105 & 226 & $2,626,708$ \\
\hline $\begin{array}{l}\text { Thousand } \\
\text { islands }\end{array}$ & 11,438 & 10,460 & 21,898 & 0 & 0 & 0 & 21,898 \\
\hline \multicolumn{1}{c}{ Total } & $4,649,334$ & $3,870,844$ & $8,520,178$ & 1,323 & 1,044 & 2.367 & $8,522,545$ \\
\hline
\end{tabular}

Source: Office of Population and Civil Registration City Administration [2].

Jakarta with a highly-dense population - an average of 12,835 people in each square kilometre - greatly disturbs development efforts that aim at establishing a prosperous society. In reality, in flood-prone areas, residents face an increasingly difficult life. Yearly occurrence of floods should be a warning to the people of Jakarta for caring and being aware of the environment. According to the theory, a form of awareness is expressed through efforts to reduce floods by: cleaning up sewage/drainage system from mud sediment, proper disposal of waste, and other social activities [3]. The form of awareness must be great since floods take place frequently; thus, public environmental awareness should be increasing.

\section{Discussion of research}

Discussion on the research is important as it will analyze the reason why the community of Jakarta, who are often affected by floods, prefer to stay in their respective places in spite of the government's frequent encouragement for them to move to other safer places.

\subsection{Purpose of the research}

This research aims at determining the level of environmental awareness knowledge of the people of Jakarta, the level of flood risk knowledge, and the behaviour of people in flood-prone areas of the environment, which affect the level of flooding risk in Jakarta. The study was conducted in SeptemberNovember 2010. The risk of flooding in Jakarta is very saddening and it is necessary to find out the actual reaction of the affected community.

\subsection{Methodology}

Survey and field observations have been employed in data collection for the research. A sample of the research was East Jakarta with respondents of the same 
behaviour characters as those of other regions. East Jakarta comprises quite a vast area and huge population. In addition, the distribution of flood-prone area in this region is widely spread. Forty families, with parents and their respective sons and daughters in each family, have been selected as samples of the study by means of purposive sampling. This made a total number of 160 respondents involved in the study. Research instruments consist of questionnaires and observation protocol. A blueprint of the questionnaire has been set up with reference to the environmental awareness indicators and sub-indicators derived from related theoretical framework, i.e., environmental knowledge and behaviour/attitude on the environment. Calibration of the instrument was performed prior to data collection (two invalid items deleted from an initial 17 items, leaving 15 items for use in the questionnaire) with instrument reliability at $(\mathrm{r})=0.81$. Simple qualitative statistical analysis (matrix and percentage) has been employed in processing the obtained data.

\subsection{Results of the research}

\subsubsection{Description of data}

Based on survey results, 2009/2010 data of the Flood Control and Evacuation Management Task Force Unit of the East Jakarta Local Government suggests ten flood-prone districts in the region. More information can be observed in the data presented in Table 2.

Table 2: $\quad$ Flood-prone districts and sub-districts in East Jakarta region.

\begin{tabular}{|c|l|c|l|l|}
\hline No. & Flood-Prone Districts & $\begin{array}{c}\text { Sub-district/ } \\
\text { Population }\end{array}$ & $\begin{array}{l}\text { Sub-district/ } \\
\text { sample }\end{array}$ & Remarks \\
\hline 1 & Pulogadung & 4 & Five sub-districts & \\
2 & Matraman & 1 & selected by random & Twenty-seven \\
3 & Jatinegara & 5 & sampling: & flood-prone \\
4 & Kramat Jati & 1 & Pekayon, Kebon & sub-districts \\
5 & Pasar Rebo & 4 & Manggis, Kayu & were identified in \\
6 & Cakung & 3 & Putih, Cipinang & ten existing \\
7 & Duren Sawit & 3 & Muara, and Lubang & districts \\
8 & Makasar & 1 & Buaya & \\
9 & Cipayung & 1 & & \\
10 & Ciracas & & \\
\hline
\end{tabular}

\subsubsection{Residents' perception}

Data was collected by means of questionnaire and observation protocol from flood-affected residents. Questionnaires were completed by 160 respondents, who came from 40 families: 40 father respondents, 40 mother respondents, 40 son respondents and 40 daughter respondents. Field data was then tabulated and summarized with reference to the set out indicators; i.e. knowledge and behaviour/attitude on environment. 


\subsubsection{Environmental awareness knowledge}

Knowledge is everything we have in our understanding that comes from practice. Practice produces experience and experience produces knowledge. Knowledge of environmental awareness is the experience of caring for the environment, cleaning up sewage/drainage system, disposing of waste properly, etc. According to Husserl cited in Brauwer, awareness is the conscious mind or knowledge that controls reasoning, conscious living, part of attitude and behaviour, and is described as a phenomenon of nature that must be explained based on causality principles [4]. Joseph Murphy, consciousness is one's state of awakeness or awareness of his/her own behaviour, i.e. the conscious mind that controls the mind and determine one's desired choices/preference such as good or bad [5]. Controlling flood in Jakarta is not enough just by calling a warning to be wary of potential floods; more active action is necessary to eliminate major problems that trigger the floods. As a matter of fact, in the case of floods, lack of environmentally aware behaviour has been the root problem. Thus, such behaviour needs be changed into environmentally aware behaviour. To be clearer, data related to environmental awareness knowledge is presented in Table 3 .

Indicators of the level of environmental awareness knowledge of Jakarta people presented in Table 3 are of behaviour; they refer to one's behaviour on his/her immediate environment that are results of his/her knowledge. The indicators, among others, are maintaining cleanliness of the environment, care

Table 3: Level of environmental awareness knowledge of Jakarta community.

\begin{tabular}{|c|c|c|c|c|c|c|}
\hline \multirow[b]{2}{*}{ No. } & \multirow[b]{2}{*}{ Statements } & \multicolumn{4}{|c|}{ Percentage (\%) } & \multirow{2}{*}{\begin{tabular}{|c|} 
High \\
Percentage \\
(\%)
\end{tabular}} \\
\hline & & Father & Mother & Son & daughter & \\
\hline 1. & $\begin{array}{l}\text { Maintaining cleanliness of } \\
\text { the environment }\end{array}$ & 32.50 & 10.00 & 5.00 & 12.50 & 15.00 \\
\hline 2. & Caring for the environment & 15.00 & 30.00 & 25.00 & 17.50 & 21.88 \\
\hline 3. & Protecting the environment & 17.50 & 10.00 & 5.00 & 12.50 & 11.25 \\
\hline 4. & $\begin{array}{l}\text { Maintaining the } \\
\text { environment }\end{array}$ & 15.00 & 22.50 & 10.00 & 15.00 & 15.63 \\
\hline 5. & $\begin{array}{l}\text { Attempting environment } \\
\text { conservation }\end{array}$ & 7.50 & 5.00 & 7.50 & 7.50 & 6.87 \\
\hline 6. & Disposing of waste properly & 5.00 & 7.50 & 17.50 & 7.50 & 9.38 \\
\hline 7. & Cleaning up the environment & 2.50 & 2.50 & 10.00 & 5.00 & 5.00 \\
\hline 8. & Keeping a natural living place & 5.00 & 7.50 & 5.00 & 5.00 & 5.62 \\
\hline 9. & $\begin{array}{l}\text { Performing the green } \\
\text { revolution/reforestation }\end{array}$ & - & 2.50 & 2.50 & 7.50 & 4.16 \\
\hline 10. & $\begin{array}{l}\text { Living a healthy and clean } \\
\text { life; Keeping a love for the } \\
\text { environment }\end{array}$ & - & 2.50 & 12.50 & 10.00 & 8.33 \\
\hline
\end{tabular}


for their environment, love of the environment, dispose of trash in its place, reforestation activities and so on. As presented in Table 3, there are indicator statements with higher percentage score than others. The scores reflect the respondents' level of environmental awareness knowledge. Each of the indicator statement items represents the level of environmental awareness knowledge of the community. The indicator that obtains the highest score is the Caring for the Environment indicator, which determines the level of environmental awareness knowledge of the community. Therefore, the level of environmental awareness knowledge of the Jakarta community, according to analysis results, is $21.88 \%$.

\subsubsection{Knowledge of flood risks}

When the rainy season arrives, some regions in Indonesia, especially Jakarta floods always take place. In 2010 and early 2011, Indonesia received abundant rain fall, and again there was flood in every province. Floods that occurred across Indonesia are caused by overflowing rivers. Regions where floods often occur are those stretched out along the rivers. To anticipate the catastrophic floods that often occur, it is necessary to clean up or dredge the river bed (there are sixteen rivers in Jakarta). Dredging activities attempted by the government are quite positive. Yet, since the root of problems is not addressed, then, a month later, the rivers will be full again with rubbish. Due to high rainfall, rivers in Jakarta overflow and floods occur. The potential risk of floods is enormous, including the potential loss suffered by the industry located in close-to-river regions. Areas that should have served as a water shed, in the rainy season, turn into flood supplier. On the contrary, in the dry season, the river flow is reduced drastically so that it is hot and dry in the city.

Today attempts to control floods in Jakarta have changed in terms of paradigm and actions. Disaster management is focused more on community participation in the management. Thus, the community are not merely victims or objects of the disaster, but also as disaster management actors. This communitybased program encourages or motivates community capacity empowerment to be alert in preventing and eliminating risks and the impact of floods that occur in their immediate living environment. The growth of development in Jakarta is going fast, yet, lack of attention for the city layout structure, which only contributes towards flood risks. Furthermore, the very little amount of open, green space has led to a lack of water catchment areas that can also cause floods. Therefore, when rain comes, even a large water canal will quickly overflow. Lack of maintenance of the drainage systems in several locations has been the cause of floods. Findings of field surveys and observations provide evidence that citizens who are often exposed to floods have very poor knowledge about floods. Data on the knowledge of flood-victim respondents is presented in table 4.

The Jakarta local government is aware that there is a lack of green open space as a water shed; therefore, the Governor plans to expand the green open space area in Jakarta. The city is about $650 \mathrm{~km}^{2}$. According to legislations, the ideal green open space is $30 \%$ of the total area. It now has only $9.8 \%$ [6]. Data on the level of knowledge of flood risks presented in Table 4 shows several indicators that demonstrate the society's level of knowledge of flood disaster. The indicator 
Table 4: $\quad$ Level of knowledge of flood.

\begin{tabular}{|c|c|c|c|c|c|c|}
\hline \multirow[b]{2}{*}{ No. } & \multirow[b]{2}{*}{ Statements } & \multicolumn{4}{|c|}{ Percentage (\%) } & \multirow{2}{*}{$\begin{array}{c}\text { High } \\
\text { Percentage } \\
\text { (\%) }\end{array}$} \\
\hline & & Father & Mother & Son & Daughter & \\
\hline 1. & $\begin{array}{l}\text { Rains in the upland, overflowed } \\
\text { rivers upland, flood occurs in } \\
\text { lowland. }\end{array}$ & 42.50 & 50.00 & 40.00 & 40.00 & 43.12 \\
\hline 2. & $\begin{array}{l}\text { Flood originates from a higher } \\
\text { location }\end{array}$ & 17.50 & 25.00 & 5.00 & - & 15.83 \\
\hline 3. & $\begin{array}{l}\text { Flood has been due to rain } \\
\text { water supply from Bogor }\end{array}$ & 15.00 & 10.00 & 22.50 & - & 15.83 \\
\hline 4. & $\begin{array}{l}\text { Flood originates from other } \\
\text { higher place/land }\end{array}$ & 10.00 & 7.50 & 5.00 & 22.50 & 11.25 \\
\hline 5. & $\begin{array}{l}\text { Continuous rain in Bogor has } \\
\text { incurred flood }\end{array}$ & 7.50 & 7.50 & 12.50 & 7.50 & 8.75 \\
\hline 6. & $\begin{array}{l}\text { Flood was due to overflowing } \\
\text { rivers in Bogor }\end{array}$ & 5.00 & - & 10.00 & - & 7.50 \\
\hline 7. & $\begin{array}{l}\text { Flow of rain water from Bogor } \\
\text { cannot be blocked }\end{array}$ & 2.50 & - & - & 10.00 & 6.25 \\
\hline
\end{tabular}

with a high percentage score is a flood coming from upland areas. This indicator suggests that when there is heavy rain upland, flood will take place in low areas. Controlling the flood can be done by means of concrete actions; i.e. by training people to not only be sufferers in the disaster but act as actors in disaster management as well. The highest score is obtained by the 'upland area' indicator. Therefore, there is a need to find out their level of knowledge about flood due to the fact that flood can occur at any time. In Table 4, indicators of knowledge about flood risks can be observed. Each indicator item represents the level of knowledge about flood risks of the Jakarta people. Thus, with reference to data analysis results, the level of knowledge about flood risks of the Jakarta people is $43.12 \%$.

\subsubsection{Flood-affected citizens refuse to move out of the flood-prone areas}

As a matter of fact, the Jakarta local government is actually so experienced in handling flood risks that they can minimize gaps and weaknesses. Jakarta citizens, particularly those who are affected by floods and live by the river banks, understand well that their living area is subject to recurring floods. They are not allowed to remain in the flood-prone areas or by the river banks. Yet, this is difficult to implement since they are not willing to be relocated or move to other residential areas. To be clearer, Table 5 presents data on flood victims who are not willing to move from flood-prone areas.

Data presented in Table 5 shows the proportion of flood victims who refuse to move from flood-prone areas. They become a burden to the local government who has been responsible for taking good care of them until now. On studying the indicators that represent reasons for residents refusing to move from their current living area, some surprising things can be observed. Their reasons 
Table 5: Percentage of flood victims who refuse to move from flood-prone areas.

\begin{tabular}{|l|l|l|l|l|c|c|}
\hline \multirow{2}{*}{ No } & \multicolumn{1}{|c|}{ Statements } & \multicolumn{4}{|c|}{ Percentage (\%) } & High Percentage \\
\cline { 3 - 7 } & & Father & Mother & Son & Daughter & (\%) \\
\hline $\mathbf{1 .}$ & Have no funding support & 42.50 & 32.50 & - & - & 18.75 \\
\hline $\mathbf{2 .}$ & $\begin{array}{l}\text { Already feels comfortable } \\
\text { living in current place }\end{array}$ & 27.50 & 42.50 & 50.00 & 55.00 & 43.75 \\
\hline $\mathbf{3 .}$ & $\begin{array}{l}\text { Have not yet found a } \\
\text { better place to live }\end{array}$ & 15.00 & 12.50 & - & - & 6.88 \\
\hline $\mathbf{4 .}$ & $\begin{array}{l}\text { Current flood-prone area } \\
\text { is a very strategic place to } \\
\text { live }\end{array}$ & 12.50 & 12.50 & 17.50 & 20.00 & 15.62 \\
\hline $\mathbf{5 .}$ & $\begin{array}{l}\text { Current house brings } \\
\text { great luck }\end{array}$ & 2.50 & - & - & - & 0.63 \\
\hline $\mathbf{6 .}$ & $\begin{array}{l}\text { Currently living with } \\
\text { parents }\end{array}$ & - & - & 32.50 & 25.00 & 14.38 \\
\hline
\end{tabular}

includes no funding support for moving to other place and Already feels comfortable living in current place. This is indeed surprising. Despite their being threatened by risks of flood, they feel comfortable, happy and safe, living in that place. Based on data in Table 5, the percentage of people who are not willing to be relocated from flood-prone areas for they do not have sufficient funding to do so is quite a lot too. There are also residents who are not willing to be relocated because they still live with their parents who live in the flood prone areas. Some others remain to live in the flood-prone areas because the location is strategic and brings good luck to them. Yet, the most surprising indicator is the fact that they are not willing to move because they feel comfortable living there. This indicator obtains a percentage score of $43.75 \%$. These findings can be considered true as relocating residence from flood-prone areas is quite difficult and becomes a great burden to Jakarta local government.

\subsubsection{Community's attitude on environment}

It has been explained that the Jakarta local government's efforts to manage the risks of yearly flood is quite great. This is because the disaster management efforts experience a change in terms of paradigm and concrete actions. Disaster management has been focused on community participation in managing the flood disaster. This community based program encourages community capacity empowerment to be alert for preventing and eliminating the accompanying impact and risks on the immediate environment. This program has been implemented for the community as affected subjects need to be empowered by providing them with the necessary knowledge and skills that will enable them to manage impact of the disaster and eliminate the risks of flood. The Jakarta local government has attempted maximum efforts in controlling flood risks. However, the researcher observes that they have not yet fully addressed the fundamental aspects, i.e. attitude and behaviour, which is important in order to reset the existing mindset of the people to a new mindset that is acceptable to the whole community. Michael O'Driscoll states that issues related to changes in attitude 
also involve a self-motivation in attempting the change. Efforts to encourage a change in attitude usually occur following exposure to new or a different piece of information about the object or problem in question [7].

The above statement signifies that a change in attitude also requires modification prior to establishment of the newly acquired belief. Such way of thinking brings differences between two major strategies for changing attitudes; that is, active participation and persuasive communication. Besides, compliance occurs when one receives the influence of other(s) for social acceptance reasons. As an approach, active participation strategy requires active involvement of individuals, which is determined by the individuals' contact with the government who functions as initiator. Survey and observation reveal data on the community's attitude to their immediate living environment related to risks of flood. An indicator of the community's attitude through concrete actions on the flood-prone environment can be observed in Table 6 .

One indicator statement in the table shows quite a low level of environment awareness knowledge; i.e. does not feel sad or disappointed on seeing illegal constructions alongside the river $(28.75 \%)$. However, when the average score of indicators of behaviour is calculated, the result comes to $47.25 \%$. This indicates that people living in the flood-prone areas are not yet performing an environmentally friendly behaviour. This description signifies that human beings should make friends with their immediate living environment; else, they will be disadvantaged. Chiras emphasizes that men are part of nature. They are not superior to nature. They are dependent on their immediate living environment that they need to always think of taking care of nature and cannot live without [8].

In reality, this is not the case. People seem to be unfriendly to their environment. Their daily conversations seem to suggest that they get along well with their environment, yet, it is not reflected in their actions. This goes on and shows that the Jakarta community remains less friendly with their environment or shows a lack of environmental awareness, particularly when it comes to taking care of the environment in flood-prone areas. Similarly, the drainage system in Jakarta, which is mostly of a closed type, cannot be expected to function properly as it is full of garbage/rubbish and in need of cleaning/dredging. Indeed, this may incur great cost. Furthermore, the local government has not yet shown firmness in promoting discipline and implementing regulations on environmental issues [9]. They fail in issuing warnings or applying penalties to people who dispose of waste carelessly. Therefore, the core problem in environmental awareness issues lies in the behaviour of the people or the community. Regulations are made to be obeyed and implemented firmly by all members of the community including the leaders. In other words, environmental awareness, particularly the flood disaster management efforts, can be established when all members of the community are involved, i.e. the leaders and followers/citizens. Leaders are expected to be models in caring for environment activities. Particularly in Jakarta, they need to be firm in building discipline related to environmental care. It is necessary to apply a sanction for improper waste disposal practices with local government regulations as reference [10]. Existing 
regulations should be applied properly and firmly. Causes of yearly floods and traffic jams in Jakarta are our own practices, human actions, and we should not blame each other or nature for the problems earned.

Table 6: Data on community behaviour on the environment in flood-prone location.

\begin{tabular}{|c|c|c|c|c|c|}
\hline \multirow[b]{2}{*}{ No. } & \multirow[b]{2}{*}{ Statements } & \multicolumn{3}{|c|}{ Percentage (\%) } & \multirow{2}{*}{$\begin{array}{c}\text { High } \\
\text { Percentage } \\
\text { (\%) }\end{array}$} \\
\hline & & 1 & 2 & 3 & \\
\hline 1. & Cleaning the drainage in home front & 16.80 & 42.50 & 37.50 & 42.50 \\
\hline 2. & Given the task of sweeping garbage & 5.00 & 35.00 & 60.00 & 60.00 \\
\hline 3. & Social service work with parents & 17.50 & 41.25 & 41.20 & 41.25 \\
\hline 4. & Planting trees in the yard & 30.62 & 39.30 & 30.00 & 39.30 \\
\hline 5. & Make an absorption hole or bio-pore & 25.62 & 33.75 & 40.62 & 40.62 \\
\hline 6. & Sad when flooding & 25.00 & 36.87 & 51.25 & 51.25 \\
\hline 7. & $\begin{array}{l}\text { Not sad to see illegal buildings along side } \\
\text { of the river }\end{array}$ & 11.87 & 19.75 & 28.75 & 28.75 \\
\hline 8. & Setting up the levee board retaining flood & 47.50 & 23.62 & 50.00 & 50.00 \\
\hline 9. & $\begin{array}{l}\text { Processing of organic waste becoming } \\
\text { fertilizer }\end{array}$ & 26.62 & 39.38 & 25.00 & 39.38 \\
\hline 10. & Creating high homes & 34.38 & 13.12 & 79.40 & 79.40 \\
\hline \multicolumn{5}{|c|}{ Average Percentage } & $47.25 \%$ \\
\hline
\end{tabular}

According to Engel and Engel, proper development must correspond with high level human activities; that is, in obtaining the values of life, man must live properly on earth with regard to environmental ethics. It is because the earth is theirs, but not exclusive to them. Furthermore, the end of a development should be a better state [11]. For this reason, it is necessary for development activities in Jakarta to consider carefully existing physical environment, climate, and aspects related to city plan and lay-out. In other words, it sufficiently attends to availability of green open space and non-green one to function as a watershed for the city as well as improving the poor drainage system. It is recommended that the function of wetlands that have been closed for housing development be restored, reduce the use of building materials or paving materials in the form of asphalt, concrete and cement that are not water absorbent, and replace them with more environmental friendly materials. Besides, water is one source of life that should be utilized wisely instead of turning it into disaster for people. Eventually, it is realized that the risk of floods that occurs annually has been the result of us not taking advantage of the rain as God's blessing. In fact, the rainy season brings about terrible disaster to people. On the contrary, in the dry season, flood-prone areas experience water shortage or drought. Such a situation signifies the inability of human beings in taking best advantage of God's abundant blessing. Therefore, it is necessary to learn from nature that God provides us with. 


\section{Conclusion}

In conclusion, the level of environmental awareness knowledge of community in Jakarta is $21.88 \%$; level of knowledge about risk of floods is $43.12 \%$, people's behaviour on the environment in locations vulnerable to floods is $47.25 \%$, and flood victims who are not willing to move from flood-prone areas is $43.7 \%$. The low level of awareness has been influenced by the diverse cultures, science and technology, and globalization. Competition in life, which is quite high, hard, and difficult, has left people with no time to think about caring for the environment. It is expected that the community demonstrate positive behaviour by practising environmentally aware actions such as the proper disposal of waste/trash, cleaning up the drainage system from trash, and supporting the government's flood control and risk management programs. All efforts attempted by Jakarta local government can be considered optimum and need to be supported by the whole community.

Attitude and behaviour aspects are so important that they should be a concern to us. There is a need to change the mindset of the society into one that cares about the environment. Jakarta local government needs to change or improve its method of communication into a participatory method of communication through harmonious and persuasive participation with the people in the flood-prone areas. This needs to be done with a view to helping people living in flood-prone areas to understand the threatening danger occurring every year and make them willing to move to safer and more comfortable living areas. Therefore, it is important for development efforts to be guided by existing city layout plans; that aim at improving current poor drainage system management and, in general, controlling the abundant water supply in the rainy season, and making the best of it to support prosperity of the people rather than turning it into a catastrophe.

\section{References}

[1] Sajogyo, Pudjiwati. Development Sociology. Jakarta: FPS IKIP Jakarta and BKKBN Jakarta, pp.119-128, 1985.

[2] Office of Population and Civil Registration City Administration, 2010

[3] Neolaka, Amos. Environmental Awareness. Jakarta: Rineka Cipta, pp. 7986, 2008.

[4] Husserl who quoted Brauwer, M.A.W. Human Body in the Light of Psychology Phenomenologist. Jakarta: Gramedia, pp.56-65, 1986.

[5] Murphy, Joseph (1988). Generating Power of the Subconscious. Bandung: Pionir Jaya CV, pp. 19-25, 1988.

[6] National Disaster Management Agency. Disaster Management Floods Jakarta: Public relations. Jakarta, 29-11-2010.

[7] Michael O'Driscoll, Godfrey Gardner, J Michael Innes, Joseph P. Forgas Philip L Pearce, James W. Newton. (1981). Social Psychology. Sydney: Prentice-Hall of Australia Pty Ltd, pp. 294-301. 1981. 
118 Flood Recovery Innovation and Response XI

[8] Chiras, Daniel D (1991). Environment Science Action for a Sustainable Future. California The Benjamin/Cumming Publ. Company Inc. Third. Ed., pp. 454-464, 1991.

[9] RI Law No.32 on the Protection and Management Environment, 2009

[10] Government Regulation No15 About Implementation of spatial, 2010

[11] Engel, Ronald .J \& Engel, Joan Gibb (1990). Ethics of Environment and Development, Global Challenge and International Response. London: Belhaven Press, pp. 27-40, 1990. 